\section{Kidney \\ Blood Pressure \\ Research}

Kidney Blood Press Res 2015;40:66-76

DOI: $10.1159 / 000368483$

Published onlıne: February 24, 2015

(C) 2015 S. Karger AG, Basel

www.karger.com/kbr

Accepted: January 20, 2015

$1423-0143 / 15 / 0401-0066 \$ 39.50 / 0$

This is an Open Access article licensed under the terms of the Creative Commons AttributionNonCommercial 3.0 Unported license (CC BY-NC) (www.karger.com/OA-license), applicable to the online version of the article only. Distribution permitted for non-commercial purposes only.

Review

\title{
Drug Resistant Hypertension - No SIMPLE Way Out
}

\author{
Janusz Skrzypecki Marcin Ufnal \\ Department of Experimental and Clinical Physiology, Laboratory of Centre for Preclinical Research, \\ Medical University of Warsaw, Warsaw, Poland
}

\section{Key Words}

Hypertension - Renal denervation - Blood pressure - Heart failure Chronic kidney disease • Sleep apnea syndrome $\cdot$ Metabolic syndrome

\begin{abstract}
Hypertension poses growing challenge for health policy-makers and doctors worldwide. Recently published results of Symplicity-III trial (HTN-3), the first blinded, randomized, multicenter study on the efficacy of renal denervation for the treatment of resistant hypertension did not show a significant reduction of BP in patients with resistant hypertension 6 months after renal-artery denervation, as compared with controls. In this paper we review clinical and experimental studies on renal denervation. In order to identify causes of inconsistent results in renal denervation studies we look at basic science support for renal denervation and at designs of clinical trials.
\end{abstract}

Copyright @ 2015 S. Karger AG, Basel

\section{History of antihypertensive treatment}

Hypertension poses growing challenge for health policy-makers and doctors worldwide. It has been estimated that $26 \%$ of the population was hypertensive in 2000 and this percentage is bound to increase to almost $30 \%$ by 2025 [1]. The history of hypertension is relatively short. In 1905, Korotkoff described a non-invasive, auscultatory method of determining systolic and diastolic blood pressure (BP) [2]. The discovery that high BP is correlated with an increased mortality dates back to the beginning of the 20th century. First assumptions were made in 1906, but clear epidemiological data was presented in 1939 by the Actuarial Society of America. While insurance companies quickly adopted this epidemiological data in their risk assessment protocols, it took some more time until it was widely accepted by the physicians $[3,4]$.

The early methods of antihypertensive treatment included a surgical sympathectomy, an invasive procedure based on the removal of thoracic, abdominal or pelvic sympathetic 


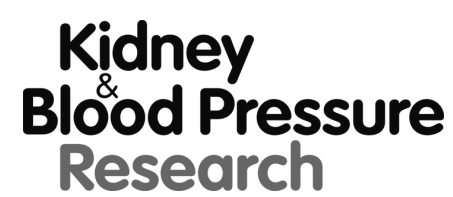

\begin{tabular}{l|l}
\hline \multicolumn{2}{l}{ Kidney Blood Press Res 2015;40:66-76 } \\
\hline \begin{tabular}{l|l} 
DOI: $10.1159 / 000368483$ \\
Published onlıne: February 24, 2015
\end{tabular} & $\begin{array}{l}\text { C } 2015 \text { S. Karger AG, Basel } \\
\text { www.karger.com/kbr }\end{array}$ \\
\hline
\end{tabular}

Skrzypecki/Ufnal: Renal Denervation in Hypertension

ganglia. Results were not satisfactory and hypotensive effect was found only in $50 \%$ of the treated patients. Furthermore, the sympathectomy was associated with many adverse effects, including periprocedural death. Therefore, as soon as antihypertensive drugs were developed, the sympathectomy was abandoned [5-10]. First antihypertensives were hexamethonium and pentolinium. They were shown to significantly reduce arterial BP by inhibiting the sympathetic activity. However, again, due to multiple side effects, they have not become widely used $[5,10]$. The road to safe and effective antihypertensive drugs has been long, paved with numerous moderately successful compounds, such as methyldopa or clonidine $[11,12]$. The introduction of thiazide diuretics (1958), beta blockers (1973), calcium channel blockers (1981), angiotensin converting enzyme inhibitors (1982), and angiotensin receptor blockers (1995) marks big milestones in the search of efficient antihypertensive treatment [13].

Although many effective drugs have been developed, it is estimated that about $10 \%$ of patients do not respond with a sufficient reduction in BP [14]. Apart from that, some people do not adhere to the treatment regimen due to drugs' side effects, mental disability or medication phobia.

\section{Renal denervation in drug-resistant hypertension}

Drug resistant hypertension is defined as BP of over 140/90, despite the treatment with three different antihypertensive drugs, including diuretic in maximal tolerable doses. The precise number of patients diagnosed with drug resistant hypertension remains unknown, however, some studies estimate that it may reach about 10\% [14]. It triggers the search for new, non-pharmacological therapies, such as stimulations of baroreceptors and renal denervation [15-18].

As early as in 1935, Page and Heure described renal denervation. They found no significant effect of bilateral renal denervation in a 25-year old hypertensive woman suffering from severe essential hypertension and concluded that the results gave no ground for expecting that denervation in cases of essential hypertension was of therapeutic value [19].

The first study showing that percutaneous renal denervation is effective and safe in the treatment of drug resistant hypertension was published in 2009 in Lancet [20]. Since then, the efficacy of this method has been evaluated in various clinical settings, such as heart failure, chronic kidney disease and obstructive sleep apnea [21-24].

\section{Early studies}

Early studies presented encouraging results. First, HTN-1 (Symplicity -I), a non-blinded, non-randomized observational study showed that mean arterial pressure was significantly lower at 1, 3, 6, 9 and 12 months in patients who underwent the renal denervation in comparison to controls. The final report of a 3-year follow-up also confirmed the efficacy of the treatment $[20,25]$. In that study, 45 patients diagnosed with drug resistant hypertension underwent the renal denervation, while five patients who were excluded from the denervation due to anatomical criteria served as a control group. It was followed by optimistic results of HTN-2 (Symplicity - II), which was a non-blinded, randomized study. It enrolled patients with office systolic BP of over $160 \mathrm{mmHg}$ (or $150 \mathrm{mmHg}$ and diabetes), despite antihypertensive therapy with three or more drugs. From the group of 106 enrolled patients, 52 were assigned to renal denervation and 54 were included in a control group. Six- and twelve-month follow-up showed that patients with renal denervation had significantly greater decrease in office arterial BP than controls [26, 27]. Further evidence for the efficacy of renal denervation in the treatment of hypertension came from other small studies. Namely, Mahfoud et al. showed that renal denervation may be beneficial for patients with moderate resistant hypertension defined as a systolic BP between $140 \mathrm{mmHg}$ and $160 \mathrm{mmHg}$ [28]. Besides, Lenski and collaborators found an increase in the quality of life three months after the renal denervation in patients with resistant hypertension [29]. 


\section{Kidney Blood Pressure Research}

Skrzypecki/Ufnal: Renal Denervation in Hypertension

However, the designs of HTN-1 and HTN-2 studies have raised many concerns. The lack of blinding and the lack of sham group have been highlighted as major limitations [30]. Furthermore, inclusion criteria were based on office blood pressures while it has been shown previously that in resistant hypertensive patients higher ambulatory blood pressure predicts cardiovascular morbidity and mortality, whereas office blood pressure has no prognostic value [31]. Moreover, it has been claimed that the criteria of resistant hypertension adopted in the HTN-1 and HTN- 2 studies were not strict enough, and that the lack of a biochemical testing for compliance led to false diagnoses and enrollments [32]. In this context, Elmula and collaborators found that from the group of 18 patients who meet HTN-1 criteria of resistant hypertension and were referred by physicians for renal denervation, 12 patients did not fulfill the criteria of truly resistant hypertension and were excluded from the study because of undiagnosed primary aldosteronism, renal artery abnormalities and drug non-adherence. Furthermore, only 2 out of 6 patients who qualified for renal denervation showed a consistent decrease in BP [33]. All these objections were supposed to be addressed in the rigorously designed HTN-3 trial.

\section{HTN-3 trial}

Symplicity-III (HTN-3), a controlled, blinded, randomized study enrolled 535 patients treated in 87 US medical centers. It is currently the largest trial on renal denervation and it is the only study that includes sham-operated control group [34, 35]. At the enrollment, patients had office systolic BP of $160 \mathrm{mmHg}$ or more, despite having been treated with maximal tolerable doses of 3 different hypotensive drugs, including a diuretic. Major exclusion criteria included inappropriate renal artery anatomy, renal failure and secondary hypertension [35]. Symplicity-III (HTN-3) showed that there was no significant difference in office systolic BP and $24 \mathrm{~h}$ ambulatory BP between the controls and the renal denervation group at 6 months of a follow-up. For many, the results of HTN-3 trial came as a disappointment. The results made the experts verify highly optimistic statements and guidelines on the role of renal denervation in hypertension treatment. Scientists responsible for evaluation of Symplicity III results concluded: "a significant effect on systolic BP was not observed. Further evaluation in rigorously designed clinical trials will be necessary (...) to confirm previously reported benefits of renal denervation in patients with resistant hypertension" [34].

However, it is worth noting, that a subgroup analysis showed several non-significant differences between the denervation group and the sham procedure group, which could become significant with a longer follow-up and larger number of study participants. For example, there was a trend towards a better response in the subgroup of patients treated with aldosterone antagonists. Besides, HTN-3 subgroup analysis revealed differences between the races. There were 140 Afro-Americans(AA) and 394 non-Afro-Americans(non-AA) enrolled and randomized in the study. Researchers observed significant response to renal denervation only among non-AA. On the other hand, sham procedure induced greater reduction in SBP among AA than non-AA. Such data may suggest that the effects of renal denervation may depend on additional factors which should be considered when selecting patients for the procedure. Finally, the results of the HTN-3 study might be affected by technical issues, such as different level of experience of operators from 87 study centers or selection of a renal denervation device. These issues are especially important as no marker to confirm efficacy of renal denervation is available [36].

\section{Renal denervation in other cardiovascular diseases}

\section{Heart failure}

Heart failure results in renal hypoperfusion, which triggers the activation of the sympathetic nervous system, and leads to deterioration of the heart's pumping ability [37, 38]. Therefore, it was suggested that lesion of the neural connection between kidneys and central nervous system may be beneficial in heart failure [39]. 


\section{Kidney Blood Pressure Research}

As the results from animal studies were optimistic, [40] and HTN-1 and HTN-2 trials confirmed safety of the renal denervation, two small clinical trials, Symplicity - HF (Renal denervation in Patients with Chronic Heart Failure and Renal Impairment Clinical Trial) and REACH (Renal Artery Denervation in Chronic Heart Failure) have been launched. Early results from REACH study are promising. All patients $(n=7)$ who underwent renal denervation showed improvement in terms of symptoms and six minute walk distance. Loop diuretic was reduced or stopped in 4 patients due to reduction in peripheral edema and there were no periprocedural complications [41].

\section{Chronic Kidney Disease}

Increased renal sympathetic activity is well-documented in chronic kidney disease [42]. Observational study performed in 15 patients with chronic kidney disease showed a significant decrease in mean BP and non-significant decrease in proteinuria, glycated hemoglobin and brain natriuretic peptide (BNP) levels. Furthermore, no deterioration in renal function was found, which suggests that lowered GFR should not exclude patients from renal denervation [23].

\section{Sleep apnea syndrome}

It has been suggested that renal denervation may be beneficial in patients with sleep apnea syndrome and hypertension. For example, Witkowski and collaborators found that 8 out of 10 patients undergoing renal denervation showed reduced severity of obstructive sleep apnea [21].

\section{Metabolic syndrome}

It has been shown that SNS plays a pivotal role in pathophysiology of metabolic syndrome [43]. Renal denervation gave a potential tool for restoring balance in sympathetic activity, glucose metabolism and BP [44]. Efficacy of renal denervation in the treatment of metabolic syndrome has been found in animal models [45] and in one study in humans. Namely, Mahfoud et al showed that renal denervation in hypertensive patients with metabolic syndrome improves BP values as well as glucose tolerance $[46,47]$.

\section{Basic science support for renal denervation}

Nervous system in BP control and etiology of hypertension

The significance of the nervous system in the regulation of the arterial BP was shown in the middle of nineteenth century by Bernard and Shiff $[48,49]$. In the early 1970s, Guyton proposed a model in which arterial pressure in the long-term was determined by the kidneys regulating blood volume, according to the renal function curve describing the relationship between the renal perfusion and excretion of sodium and water. In this model, the role of the nervous system was limited to short-term control of BP [50-52]. Since then, the notion that the nervous system plays a role in the short-term regulation of BP has been widely accepted, in part due to the great popularity of magnificent physiology textbook for medical students by Guyton. However, recent clinical and experimental studies [20, 53-55] suggest that the role of the nervous system in the long-term regulation of the arterial BP and the development of hypertension may have been underappreciated [56-58]. Namely, it has been shown that chronic mechanic [59] and electric stimulation of baroreflex causes long-term lowering of arterial BP [53, 60-62]. Furthermore, a growing number of experimental studies reveal multiple alterations in the brain signalling systems in animal models of hypertension [63, 64]. Finally, the ablation of renal nerves has been found to lower arterial BP in both experimental [65] and clinical settings [20].

An increased activity of the sympathetic nervous system has been well-documented in many cardiovascular and metabolic diseases, including essential hypertension, obesity, 


\section{Kidney \\ Blood Pressure Research}

Fig. 1. Hypertensive effect of renal sympathetic nerves. Renal sympathetic nerves increase arterial blood pressure via peripheral (1) and neurogenic (2) mechanisms. 1. Renal sympathetic nerves stimulates the activity of the renin-angiotensin-aldosterone system. This promotes water and sodium reabsorption in the kidneys and increases total peripheral resistance. 2. Higher concentration of blood borne angiotensin II and sodium increases sympathetic activity via neurogenic mechanisms. ERSN - efferent renal sympathetic nerves; ARSN - afferent renal

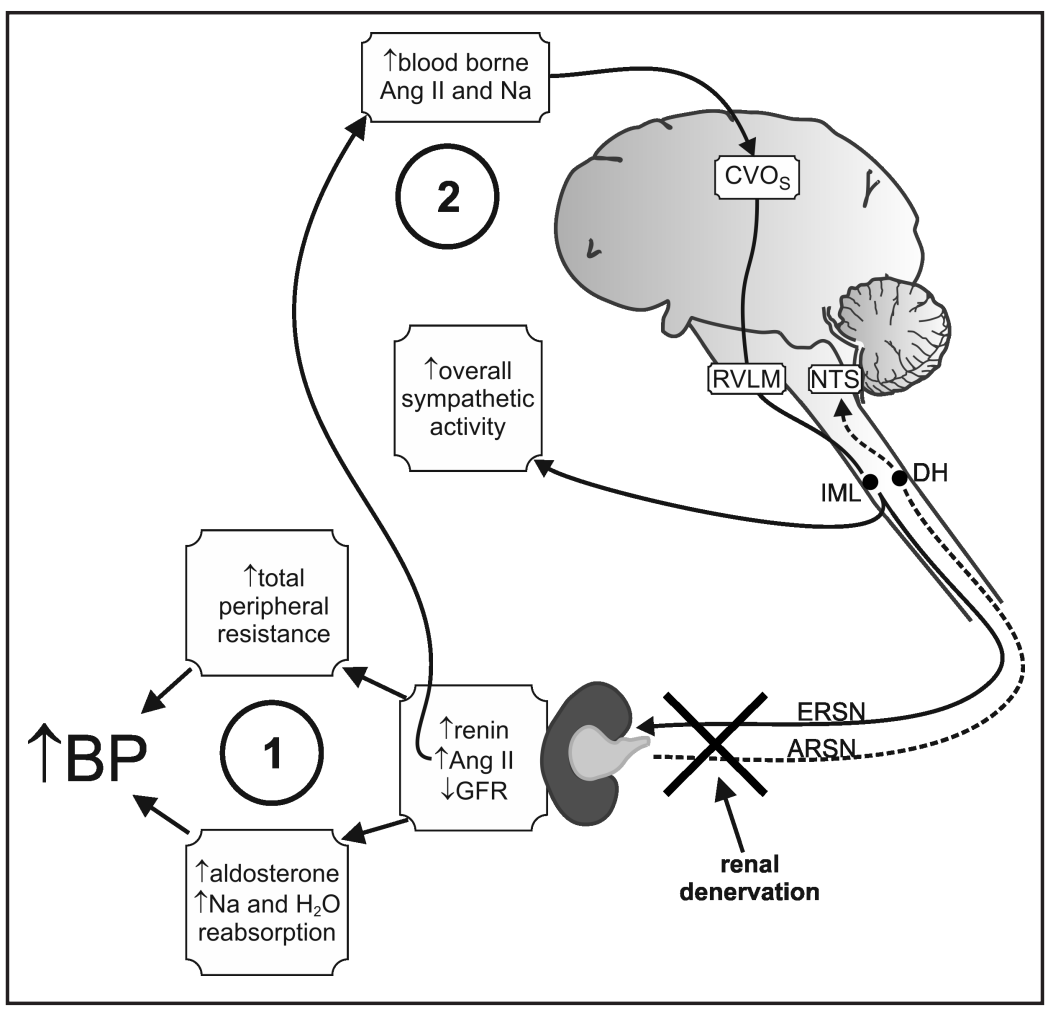
sensory nerves; Ang II angiotensin II; CVOs - the circumventricular organs, CVOs neurons sense changes in the concentration of blood borne hormones and ions as they lack the blood-brain barrier; RVLM - rostral ventrolateral medulla, comprised of presympathetic neurons; NTS - nucleus of the solitary tract; IML - spinal cord intermediolateral nucleus; DH - spinal cord dorsal horn.

obstructive sleep apnea, heart failure, polycystic ovary syndrome, atrial fibrillation [66-73]. Although the increased activity of the sympathetic nervous system may be primary as well as secondary, the pharmacological inhibition of the sympathetic system has been proven to reduce cardiovascular mortality [74].

\section{Renal nerves}

Kidneys are innervated by efferent renal sympathetic nerves (ERSN) and afferent renal sensory nerves (ARSN) [75]. ERSN terminate in renal arterial vessels, renal tubules and cells of juxtaglomerular apparatus [76]. The sympathetic stimulation of juxtaglomerular cells leads to the activation of the renin-angiotensin-system and a subsequent increase in BP via multiple mechanism [76, 77] Furthermore, Ang II interacts with the circumventricular organs in the brain and the sympathetic ganglia, which further increases the sympathetic acitivy [76, 78-82], (Figure 1).

ARSN originate in kidney vasculature and have their synapses in the NTS in the medulla oblongata. It has been found that ischemia and kidney damage increase ARSN activity, which leads to the stimulation of the sympathetic nervous system and the increase in BP [82-89]. However, the role of ARSN in human hypertension is not clear as there is no method of selective and complete ARSN lesion.

\section{Renal denervation}

The mechanisms behind the therapeutic effect of renal denervation are not clear. A likely mechanism involves a decrease in renal sympathetic activity, which reduces the stimulation of $\beta 1$-adrenoreceptors on juxtaglomerular cells and $\alpha 1$ - adrenoreceptors on renal 


\section{Kidney Blood Pressure Research}

Skrzypecki/Ufnal: Renal Denervation in Hypertension

tubules. This attenuates the secretion of renin and the tubular absorption of sodium, respectively [77, 90, 91]. In addition, renal denervation increases renal blood flow, mainly due to the interruption of sympathetic stimulation of renal arterial resistance vessels [92, 93]. In this context, the inhibition of ERSN overactivity has been found to prevent from an increase in fluid and sodium retention, a pathological sequence which often leads to hypertension and congestive heart failure [94].

Furthermore, several studies have shown that renal denervation reduces an overall sympathetic activity, i.e. diminishes the total body norepinephrine spillover and the activity of muscle sympathetic nervous system $[68,95,96]$. These may explain potential effects of renal denervation not only in hypertension, but also in wide spectrum of cardiovasular and metabolic diseases.

\section{Renal denervation - experimental studies}

The role of renal nerves and renal denervation in hypertension, heart failure and chronic kidney disease has been widely studied in many species, including rats, mice, miniature swine, sheep and dogs [44, 65, 97-103]. The experiments utilize several methodological approaches to renal denervation. The most common is surgical exposure of renal arteries and chemical coagulation of renal nerves with solution of phenol in absolute ethanol [101, 103]. Intrarenal delivery of guanethidine or 6-hydroxydopamine [104, 105], and electrical denervation has also been used [106]. Some conclusions on hemodynamic effects of renal denervation have also been drawn from experiments on kidney-transplanted animals [107].

It has been found that renal denervation lowers BP and delays the onset of hypertension in spontaneously hypertensive rats (SHR), Borderline hypertensive rat, New Zealand SHR, Stroke prone SHR $[65,68]$. Furthermore, it has been shown that ablation of afferent sensory renal nerves prevents from the development of hypertension in animal model of CKD $[108,109]$. In contrast, studies in hypertensive model of DOCA-salt sensitive rats and 1-clip Golblatt hypertension provided inconsistent results [68]. Animal studies suggest that the hypotensive effect of renal denervation is mostly due to an increased natriuresis $[106,110$, 111]. Besides, Nozawa et al. showed that renal denervation in rats with myocardial infarction improved left ventricular ejection fraction, decreased level of BNP and increased urine output [40].

\section{Conclusion}

Recently published results of HTN-3 trial, the first blinded, randomized, multicenter study on the efficacy of renal denervation for the treatment of resistant hypertension did not show a significant reduction of BP in patients with resistant hypertension 6 months after renal-artery denervation, as compared with the control. Certainly, a lesson learned from renal denervation studies should encourage the inclusion of a sham-operated group as controls in interventional cardiology trials.

It is worth noting, however, that while Symplicity III study showed that renal denervation does not lower BP in hypertensive patients receiving maximal tolerable doses of 3 different hypotensive drugs, the study did not negate the hypotensive effect of renal denervation. Additionally, HTN-3 trial proved that renal denervation is not associated with significant side effects. Currently, there is no reason to recommend the use of renal denervation as a routine procedure in drug resistant hypertension. Further, better designed studies than HTN-3 are needed to establish the role of renal denervation as a treatment option in selected groups of hypertensive patients $[17,112]$.

\section{Disclosure Statement}

The authors of this manuscript state that they do not have any conflict of interests and nothing to disclose. 


\section{Kidney \\ Blood Pressure Research}

Kidney Blood Press Res 2015;40:66-76

\begin{tabular}{l|l}
\hline DOI: 10.1159/000368483 & (c) 2015 S. Karger AG, Basel
\end{tabular}

Publisned onIIne: February 24, 2015

www.karger.com/kbr

Skrzypecki/Ufnal: Renal Denervation in Hypertension

\section{Acknowledgements}

The authors are in debt to Dr. T. Zera for his critical comments on the manuscript. This work was supported by the Ministry of Science and Higher Education of the Diamond grant DIA/2013/42.

\section{References}

1 Kearney PM, Whelton M, Reynolds K, Muntner P, Whelton PK, He J: Global burden of hypertension: Analysis of worldwide data. Lancet 2005;365:217-223.

2 Korotkoff NS: On methods of studying blood pressure. Bull Imperial Mil Med Acad 1905;11:365-367.

3 Booth J: A short history of blood pressure measurement. Proc R Soc Med 1977;70:793-799.

4 Kotchen TA: Historical trends and milestones in hypertension research: A model of the process of translational research. Hypertension 2011;58:522-538.

5 Freis ED, Finnerty FA, Jr., Schnaper NW, Johnson RL: The treatment of hypertension with hexamethonium. Circulation 1952;5:20-27.

-6 Page IH, Heuer GJ: A surgical treatment of essential hypertension. J Clin Invest 1935;14:22-26.

-7 Peet MM: Hypertension and its surgical treatment by bilateral supradiaphragmatic splanchnicectomy. Am J Surg 1948;75:48-68.

8 Grimson KS, Orgain ES, Anderson B, D'Angelo GJ: Total thoracic and partial to total lumbar sympathectomy, splanchnicectomy and celiac ganglionectomy for hypertension. Ann Surg 1953;138:532-547.

-9 Smithwick RH: Surgical treatment of hypertension. Am J Med 1948;4:744-759.

10 Dennis E, Ford R, Herschberger R, Moyer JH: Pentolinium and hexamethonium combined with rauwolfia in the treatment of hypertension. N Engl J Med 1955;253:597-600.

11 Day MD, Rand MJ: A hypothesis for the mode of action of alpha-methyldopa in relieving hypertension. J Pharm Pharmacol 1963;15:221-224.

12 Hoobler SW, Sagastume E: Clonidine hydrochloride in the treatment of hypertension. Am J Cardiol 1971;28:67-73.

13 http://wwwaccessdatafdagov/scripts/cder/drugsatfda/

14 Persell SD: Prevalence of resistant hypertension in the united states, 2003-2008. Hypertension 2011;57:1076-1080.

15 Krum H, Sobotka P, Mahfoud F, Bohm M, Esler M, Schlaich M: Device-based antihypertensive therapy: Therapeutic modulation of the autonomic nervous system. Circulation 2011;123:209-215.

-16 Papademetriou V, Doumas M, Faselis C, Tsioufis C, Douma S, Gkaliagkousi E, Zamboulis C: Carotid baroreceptor stimulation for the treatment of resistant hypertension. Int J Hypertens 2011;2011:964394.

-17 Schlaich MP, Schmieder RE, Bakris G, Blankestijn PJ, Bohm M, Campese VM, Francis DP, Grassi G, Hering D, Katholi R, Kjeldsen S, Krum H, Mahfoud F, Mancia G, Messerli FH, Narkiewicz K, Parati G, Rocha-Singh KJ, Ruilope LM, Rump LC, Sica DA, Sobotka PA, Tsioufis C, Vonend O, Weber MA, Williams B, Zeller T, Esler MD: International expert consensus statement: Percutaneous transluminal renal denervation for the treatment of resistant hypertension. J Am Coll Cardiol 2013;62:2031-2045.

18 Lohmeier TE, Iliescu R, Dwyer TM, Irwin ED, Cates AW, Rossing MA: Sustained suppression of sympathetic activity and arterial pressure during chronic activation of the carotid baroreflex. Am J Physiol Heart Circ Physiol 2010;299:H402-409.

19 Page IH, Heuer GJ: The effect of renal denervation on patients suffering from nephritis. J Clin Invest 1935;14:443-458.

-20 Krum H, Schlaich M, Whitbourn R, Sobotka PA, Sadowski J, Bartus K, Kapelak B, Walton A, Sievert H, Thambar S, Abraham WT, Esler M: Catheter-based renal sympathetic denervation for resistant hypertension: A multicentre safety and proof-of-principle cohort study. Lancet 2009;373:1275-1281.

-21 Witkowski A, Prejbisz A, Florczak E, Kadziela J, Sliwinski P, Bielen P, Michalowska I, Kabat M, Warchol E, Januszewicz M, Narkiewicz K, Somers VK, Sobotka PA, Januszewicz A: Effects of renal sympathetic denervation on blood pressure, sleep apnea course, and glycemic control in patients with resistant hypertension and sleep apnea. Hypertension 2011;58:559-565. 


\section{Kidney \\ Blood Pressure Research}

Kidney Blood Press Res 2015;40:66-76
\begin{tabular}{l|l}
\hline DOI: 10.1159/000368483 & $\begin{array}{l}\text { C) 2015 S. Karger AG, Basel } \\
\text { www.karger.com/kbr }\end{array}$ \\
\hline Published onlIne: February 24, 2015 &
\end{tabular}

Skrzypecki/Ufnal: Renal Denervation in Hypertension

22 Sobotka PA, Krum H, Bohm M, Francis DP, Schlaich MP: The role of renal denervation in the treatment of heart failure. Curr Cardiol Rep 2012;14:285-292.

-23 Hering D, Mahfoud F, Walton AS, Krum H, Lambert GW, Lambert EA, Sobotka PA, Bohm M, Cremers B, Esler MD, Schlaich MP: Renal denervation in moderate to severe ckd. J Am Soc Nephrol 2012;23:1250-1257.

24 Hering D, Esler MD, Schlaich MP: Chronic kidney disease: Role of sympathetic nervous system activation and potential benefits of renal denervation. EuroIntervention 2013;9 Suppl R:R127-135.

-25 Krum H, Schlaich MP, Sobotka PA, Böhm M, Mahfoud F, Rocha-Singh K, Katholi R, Esler MD: Percutaneous renal denervation in patients with treatment-resistant hypertension: Final 3-year report of the symplicity htn-1 study. Lancet 2014;383:622-629.

-26 Esler MD, Krum H, Schlaich M, Schmieder RE, Bohm M, Sobotka PA, Symplicity HTNI: Renal sympathetic denervation for treatment of drug-resistant hypertension: One-year results from the symplicity htn-2 randomized, controlled trial. Circulation 2012;126:2976-2982.

-27 Symplicity HTN-2 Invetigatiors, Esler MD, Krum H, Sobotka PA, Schlaich MP, Schmieder RE, Bohm M: Renal sympathetic denervation in patients with treatment-resistant hypertension (the symplicity htn-2 trial): A randomised controlled trial. Lancet 2010;376:1903-1909.

-28 Ott C, Mahfoud F, Schmid A, Ditting T, Sobotka PA, Veelken R, Spies A, Ukena C, Laufs U, Uder M, Bohm M, Schmieder RE: Renal denervation in moderate treatment-resistant hypertension. J Am Coll Cardiol 2013;62:1880-1886.

29 Lenski D, Kindermann I, Lenski M, Ukena C, Bunz M, Mahfoud F, Bohm M: Anxiety, depression, quality of life and stress in patients with resistant hypertension before and after catheter-based renal sympathetic denervation. EuroIntervention 2013;9:700-708.

-30 Howard JP, Cole GD, Sievert H, Bhatt DL, Papademetriou V, Kandzari DE, Davies JE, Francis DP: Unintentional overestimation of an expected antihypertensive effect in drug and device trials: Mechanisms and solutions. Int J Cardiol 2014;172:29-35.

-31 Salles GF, Cardoso CR, Muxfeldt ES: Prognostic influence of office and ambulatory blood pressures in resistant hypertension. Arch Intern Med 2008;168:2340-2346.

-32 Persu A, Renkin J, Asayama K, O'Brien E, Staessen JA: Renal denervation in treatment-resistant hypertension: The need for restraint and more and better evidence. Expert Rev Cardiovasc Ther 2013;11:739-749.

-33 Fadl Elmula FE, Hoffmann P, Fossum E, Brekke M, Gjonnaess E, Hjornholm U, Kjaer VN, Rostrup M, Kjeldsen SE, Os I, Stenehjem AE, Hoieggen A: Renal sympathetic denervation in patients with treatment-resistant hypertension after witnessed intake of medication before qualifying ambulatory blood pressure. Hypertension 2013;62:526-532.

-34 Bhatt DL, Kandzari DE, O'Neill WW, D'Agostino R, Flack JM, Katzen BT, Leon MB, Liu M, Mauri L, Negoita M, Cohen SA, Oparil S, Rocha-Singh K, Townsend RR, Bakris GL: A controlled trial of renal denervation for resistant hypertension. N Engl J Med 2014;370:1393-1401.

-35 Kandzari DE, Bhatt DL, Sobotka PA, O'Neill WW, Esler M, Flack JM, Katzen BT, Leon MB, Massaro JM, Negoita M, Oparil S, Rocha-Singh K, Straley C, Townsend RR, Bakris G: Catheter-based renal denervation for resistant hypertension: Rationale and design of the symplicity htn-3 trial. Clin Cardiol 2012;35:528-535.

36 Http://www.Medscape.Org/viewarticle/823471_transcript

-37 Kemp CD, Conte JV: The pathophysiology of heart failure. Cardiovasc Pathol 2012;21:365-371.

$-38$ Parmley WW: Pathophysiology of congestive heart failure. Am J Cardiol 1985;55:9A-14A.

DiBona GF, Sawin LL: Role of renal nerves in sodium retention of cirrhosis and congestive heart failure. Am J Physiol 1991;260:R298-305.

40 Nozawa T, Igawa A, Fujii N, Kato B, Yoshida N, Asanoi H, Inoue H: Effects of long-term renal sympathetic denervation on heart failure after myocardial infarction in rats. Heart Vessels 2002;16:51-56.

-41 Davies JE, Manisty CH, Petraco R, Barron AJ, Unsworth B, Mayet J, Hamady M, Hughes AD, Sever PS, Sobotka PA, Francis DP: First-in-man safety evaluation of renal denervation for chronic systolic heart failure: Primary outcome from reach-pilot study. Int J Cardiol 2013;162:189-192.

42 Rump LC, Amann K, Orth S, Ritz E: Sympathetic overactivity in renal disease: A window to understand progression and cardiovascular complications of uraemia? Nephrol Dial Transplant 2000;15:1735-1738.

43 Huggett RJ, Burns J, Mackintosh AF, Mary DA: Sympathetic neural activation in nondiabetic metabolic syndrome and its further augmentation by hypertension. Hypertension 2004;44:847-852. 


\section{Kidney \\ Blood Pressure Research}

\begin{tabular}{|c|c|}
\hline Kidney Blood Press Res 201 & \\
\hline $\begin{array}{l}\text { DOI: } 10.1159 / 000368483 \\
\text { Published onlIne: February 24, } 2015\end{array}$ & $\begin{array}{l}\text { (c) } 2015 \text { S. Karger AG, Basel } \\
\text { www.karger.com/kbr }\end{array}$ \\
\hline
\end{tabular}

Skrzypecki/Ufnal: Renal Denervation in Hypertension

44 Kassab S, Kato T, Wilkins FC, Chen R, Hall JE, Granger JP: Renal denervation attenuates the sodium retention and hypertension associated with obesity. Hypertension 1995;25:893-897.

45 Huang WC, Fang TC, Cheng JT: Renal denervation prevents and reverses hyperinsulinemia-induced hypertension in rats. Hypertension 1998;32:249-254.

46 Mahfoud F, Schlaich M, Kindermann I, Ukena C, Cremers B, Brandt MC, Hoppe UC, Vonend O, Rump LC, Sobotka PA, Krum H, Esler M, Bohm M: Effect of renal sympathetic denervation on glucose metabolism in patients with resistant hypertension: A pilot study. Circulation 2011;123:1940-1946.

47 Mahfoud F, Ewen S, Ukena C, Linz D, Sobotka PA, Cremers B, Bohm M: Expanding the indication spectrum: Renal denervation in diabetes. EuroIntervention 2013;9 Suppl R:R117-121.

48 Bernard C: Influence du grand sympathique sur la sensibilité et sur la calorification. C R Soc Biol (Paris) 1851;1851;3:163-170.

49 Schiff M: Ueber den Einfluss der Nerven auf die Gefässe der Zunge. Arch Physiol Heilk 1853;12:377-381.

50 Guyton AC, Hall JE, Lohmeier TE, Jackson TE, Kastner PR: Blood pressure regulation: Basic concepts. Fed Proc 1981;40:2252-2256.

51 Guyton AC, Coleman TG, Cowley AV, Jr., Scheel KW, Manning RD, Jr., Norman RA, Jr.: Arterial pressure regulation. Overriding dominance of the kidneys in long-term regulation and in hypertension. Am J Med 1972;52:584-594.

52 Guyton AC: Renal function curves and control of body fluids and arterial pressure. Acta Physiol Scand Suppl 1990;591:107-113.

53 Scheffers IJ, Kroon AA, Schmidli J, Jordan J, Tordoir JJ, Mohaupt MG, Luft FC, Haller H, Menne J, Engeli S, Ceral J, Eckert S, Erglis A, Narkiewicz K, Philipp T, de Leeuw PW: Novel baroreflex activation therapy in resistant hypertension: Results of a european multi-center feasibility study. J Am Coll Cardiol 2010;56:12541258.

54 Scheffers IJ, Kroon AA, de Leeuw PW: Carotid baroreflex activation: Past, present, and future. Curr Hypertens Rep 2010;12:61-66.

55 Schlaich MP, Sobotka PA, Krum H, Lambert E, Esler MD: Renal sympathetic-nerve ablation for uncontrolled hypertension. N Engl J Med 2009;361:932-934.

56 Ufnal M: Essential hypertension--is erroneous receptor output to blame? Med Hypotheses 2012;78:454458.

57 Osborn JW: Hypothesis: Set-points and long-term control of arterial pressure. A theoretical argument for a long-term arterial pressure control system in the brain rather than the kidney. Clin Exp Pharmacol Physiol 2005;32:384-393.

58 Montani JP, Van Vliet BN: Understanding the contribution of guyton's large circulatory model to long-term control of arterial pressure. Exp Physiol 2009;94:382-388.

-59 Thrasher TN: Unloading arterial baroreceptors causes neurogenic hypertension. Am J Physiol Regul Integr Comp Physiol 2002;282:R1044-1053.

60 Lohmeier TE, Hildebrandt DA, Dwyer TM, Barrett AM, Irwin ED, Rossing MA, Kieval RS: Renal denervation does not abolish sustained baroreflex-mediated reductions in arterial pressure. Hypertension 2007;49:373-379.

61 Lohmeier TE, Hildebrandt DA, Dwyer TM, Iliescu R, Irwin ED, Cates AW, Rossing MA: Prolonged activation of the baroreflex decreases arterial pressure even during chronic adrenergic blockade. Hypertension 2009;53:833-838.

62 Bakris GL, Nadim MK, Haller H, Lovett EG, Schafer JE, Bisognano JD: Baroreflex activation therapy provides durable benefit in patients with resistant hypertension: Results of long-term follow-up in the rheos pivotal trial. J Am Soc Hypertens 2012;6:152-158.

63 Veerasingham SJ, Raizada MK: Brain renin-angiotensin system dysfunction in hypertension: Recent advances and perspectives. Br J Pharmacol 2003;139:191-202.

64 Bai Y, Jabbari B, Ye S, Campese VM, Vaziri ND: Regional expression of nad(p)h oxidase and superoxide dismutase in the brain of rats with neurogenic hypertension. Am J Nephrol 2009;29:483-492.

65 Liard JF: Renal denervation delays blood pressure increase in the spontaneously hypertensive rat. Experientia 1977;33:339-340.

66 Malpas SC: Sympathetic nervous system overactivity and its role in the development of cardiovascular disease. Physiol Rev 2010;90:513-557. 


\section{Kidney \\ Blood Pressure Research}

\begin{tabular}{l|l}
\hline \multicolumn{2}{l}{ Kidney Blood Press Res 2015;40:66-76 } \\
\hline DOI: 10.1159/000368483 & $\begin{array}{l}\text { C) 2015 S. Karger AG, Basel } \\
\text { www.karger.com/kbr }\end{array}$ \\
\hline Published onlIne: February 24, 2015 &
\end{tabular}

67 Lara HE, Ferruz JL, Luza S, Bustamante DA, Borges Y, Ojeda SR: Activation of ovarian sympathetic nerves in polycystic ovary syndrome. Endocrinology 1993;133:2690-2695.

68 DiBona GF, Esler M: Translational medicine: The antihypertensive effect of renal denervation. Am J Physiol Regul Integr Comp Physiol 2010;298:R245-253.

69 Peppard PE, Young T, Palta M, Skatrud J: Prospective study of the association between sleep-disordered breathing and hypertension. N Engl J Med 2000;342:1378-1384.

70 Beske SD, Alvarez GE, Ballard TP, Davy KP: Reduced cardiovagal baroreflex gain in visceral obesity: Implications for the metabolic syndrome. Am J Physiol Heart Circ Physiol 2002;282:H630-635.

-71 Davy KP, Hall JE: Obesity and hypertension: Two epidemics or one? Am J Physiol Regul Integr Comp Physiol 2004;286:R803-813.

72 Triposkiadis F, Karayannis G, Giamouzis G, Skoularigis J, Louridas G, Butler J: The sympathetic nervous system in heart failure physiology, pathophysiology, and clinical implications. J Am Coll Cardiol 2009;54:1747-1762.

73 Arora R: Recent insights into the role of the autonomic nervous system in the creation of substrate for atrial fibrillation: Implications for therapies targeting the atrial autonomic nervous system. Circ Arrhythm Electrophysiol 2012;5:850-859.

74 McAlister FA, Wiebe N, Ezekowitz JA, Leung AA, Armstrong PW: Meta-analysis: Beta-blocker dose, heart rate reduction, and death in patients with heart failure. Ann Intern Med 2009;150:784-794.

75 DiBona GF, Kopp UC: Neural control of renal function. Physiol Rev 1997;77:75-197.

-76 DiBona GF: Physiology in perspective: The wisdom of the body. Neural control of the kidney. Am J Physiol Regul Integr Comp Physiol 2005;289:R633-641.

77 DiBona GF: Nervous kidney. Interaction between renal sympathetic nerves and the renin-angiotensin system in the control of renal function. Hypertension 2000;36:1083-1088.

78 Ufnal M, Skrzypecki J: Blood borne hormones in a cross-talk between peripheral and brain mechanisms regulating blood pressure, the role of circumventricular organs. Neuropeptides 2014;48:65-73.

-79 Smookler HH, Severs WB, Kinnard WJ, Buckley JP: Centrally mediated cardiovascular effects of angiotensin II. J Pharmacol Exp Ther 1966;153:485-494.

-80 Johns EJ, Kopp UC, DiBona GF: Neural control of renal function. Compr Physiol 2011;1:731-767.

-81 Crowley SD, Coffman TM: Recent advances involving the renin-angiotensin system. Exp Cell Res 2012;318:1049-1056.

-82 Aiken JW, Reit E: Stimulation of the cat stellate ganglion by angiotensin. J Pharmacol Exp Ther 1968;159:107-114.

83 Niijima A: Observation on the localization of mechanoreceptors in the kidney and afferent nerve fibres in the renal nerves in the rabbit. J Physiol 1975;245:81-90.

-84 Katholi RE, Woods WT: Afferent renal nerves and hypertension. Clin Exp Hypertens A 1987;9 Suppl 1:211226.

85 Oparil S, Sripairojthikoon W, Wyss JM: The renal afferent nerves in the pathogenesis of hypertension. Can J Physiol Pharmacol 1987;65:1548-1558.

-86 Janssen BJ, van Essen H, Vervoort-Peters LH, Struyker-Boudier HA, Smits JF: Role of afferent renal nerves in spontaneous hypertension in rats. Hypertension 1989;13:327-333.

87 Wang Y, Wang DH: Neural control of blood pressure: Focusing on capsaicin-sensitive sensory nerves. Cardiovasc Hematol Disord Drug Targets 2007;7:37-46.

-88 Freisinger W, Schatz J, Ditting T, Lampert A, Heinlein S, Lale N, Schmieder R, Veelken R: Sensory renal innervation: A kidney-specific firing activity due to a unique expression pattern of voltage-gated sodium channels? Am J Physiol Renal Physiol 2013;304:F491-497.

89 Ye S, Zhong H, Yanamadala V, Campese VM: Renal injury caused by intrarenal injection of phenol increases afferent and efferent renal sympathetic nerve activity. Am J Hypertens 2002;15:717-724.

90 DiBona GF: Neurogenic regulation of renal tubular sodium reabsorption. Am J Physiol 1977;233:F73-81.

91 DiBona GF: Neural control of the kidney: Functionally specific renal sympathetic nerve fibers. Am J Physiol Regul Integr Comp Physiol 2000;279:R1517-1524.

92 Navar LG: Renal autoregulation: Perspectives from whole kidney and single nephron studies. Am J Physiol 1978;234:F357-370. 


\section{Kidney \\ Blood Pressure Research}

\begin{tabular}{|c|c|}
\hline Kidney Blood Press Res 201 & \\
\hline $\begin{array}{l}\text { DOI: 10.1159/000368483 } \\
\text { Published onlIne: February 24, } 2015\end{array}$ & $\begin{array}{l}\text { (c) } 2015 \text { S. Karger AG, Basel } \\
\text { www.karger.com/kbr }\end{array}$ \\
\hline
\end{tabular}

93 Kirchheim H, Ehmke H, Persson P: Sympathetic modulation of renal hemodynamics, renin release and sodium excretion. Klin Wochenschr 1989;67:858-864.

$\$ 94$ Hall JE, Granger JP, Hester RL, Montani JP: Mechanisms of sodium balance in hypertension: Role of pressure natriuresis. J Hypertens Suppl 1986;4:S57-65.

-95 Esler M, Jennings G, Korner P, Willett I, Dudley F, Hasking G, Anderson W, Lambert G: Assessment of human sympathetic nervous system activity from measurements of norepinephrine turnover. Hypertension 1988;11:3-20.

-96 Esler M, Lambert G, Brunner-La Rocca HP, Vaddadi G, Kaye D: Sympathetic nerve activity and neurotransmitter release in humans: Translation from pathophysiology into clinical practice. Acta Physiol Scand 2003;177:275-284.

-97 Katholi RE: Renal nerves in the pathogenesis of hypertension in experimental animals and humans. Am J Physiol 1983;245:F1-14.

-98 O'Hagan KP, Thomas GD, Zambraski EJ: Renal denervation decreases blood pressure in doca-treated miniature swine with established hypertension. Am J Hypertens 1990;3:62-64.

-99 Fan L, Mukaddam-Daher S, Gutkowska J, Nuwayhid BS, Quillen EW, Jr.: Renal perfusion pressure and renin secretion in bilaterally renal denervated sheep. Can J Physiol Pharmacol 1994;72:782-787.

100 Wang W, Falk SA, Jittikanont S, Gengaro PE, Edelstein CL, Schrier RW: Protective effect of renal denervation on normotensive endotoxemia-induced acute renal failure in mice. Am J Physiol Renal Physiol 2002;283:F583-587.

101 Dias LD, Casali KR, Leguisamo NM, Azambuja F, Souza MS, Okamoto M, Machado UF, Irigoyen MC, Schaan BD: Renal denervation in an animal model of diabetes and hypertension: Impact on the autonomic nervous system and nephropathy. Cardiovasc Diabetol 2011;10:33.

102 Rippy MK, Zarins D, Barman NC, Wu A, Duncan KL, Zarins CK: Catheter-based renal sympathetic denervation: Chronic preclinical evidence for renal artery safety. Clin Res Cardiol 2011;100:1095-1101.

-103 Kline RL, Stuart PJ, Mercer PF: Effect of renal denervation on arterial pressure and renal norepinephrine concentration in wistar-kyoto and spontaneously hypertensive rats. Can J Physiol Pharmacol 1980;58:1384-1388.

104 Williams RL, Maines JE, 3rd, Pearson JE: Direct and systemic effects of guanethidine on renal function. J Pharmacol Exp Ther 1971;177:69-77.

105 Sunn N, Harris PJ, Bell C: Effects on renal sympathetic axons in dog of acute 6-hydroxydopamine treatment in combination with selective neuronal uptake inhibitors. Br J Pharmacol 1990;99:655-660.

106 Kompanowska-Jezierska E, Walkowska A, Johns EJ, Sadowski J: Early effects of renal denervation in the anaesthetised rat: Natriuresis and increased cortical blood flow. J Physiol 2001;531:527-534.

107 Sankari BR, Stowe NT, Nally JV, Gavin JP, Remzi FH, Novick AC: Transplant renal artery stenosis in a canine model: Evaluation of hemodynamic changes, renal function, and captopril renography. J Urol 1992;147:723-726.

108 Campese VM, Kogosov E: Renal afferent denervation prevents hypertension in rats with chronic renal failure. Hypertension 1995;25:878-882.

109 Campese VM, Kogosov E, Koss M: Renal afferent denervation prevents the progression of renal disease in the renal ablation model of chronic renal failure in the rat. Am J Kidney Dis 1995;26:861-865.

110 Kowalski R, Kreft E, Kasztan M, Jankowski M, Szczepanska-Konkel M: Chronic renal denervation increases renal tubular response to $\mathrm{p} 2 \mathrm{x}$ receptor agonists in rats: Implication for renal sympathetic nerve ablation. Nephrol Dial Transplant 2012;27:3443-3448.

111 Bello-Reuss E, Colindres RE, Pastoriza-Munoz E, Mueller RA, Gottschalk CW: Effects of acute unilateral renal denervation in the rat. J Clin Invest 1975;56:208-217.

112 Lobo MD, de Belder MA, Cleveland T, Collier D, Dasgupta I, Deanfield J, Kapil V, Knight C, Matson M, Moss J, Paton JF, Poulter N, Simpson I, Williams B, Caulfield MJ: Joint uk societies' 2014 consensus statement on renal denervation for resistant hypertension. Heart 2015;101:10-16. 